\title{
Pengenalan Logika dan Algoritma Pemrograman Menggunakan Program Aplikasi Komputer Scratch Bagi Siswa Usia Tingkat Dasar di SD Negeri Model Mataram
}

\author{
Andy Hidayat Jatmika*, I.W. Agus Arimbawa, Ariyan Zubaidi, \\ I.G.P Wirarama W.W., A. Zafrullah M \\ Program Studi Teknik Informatika, Fakultas Teknik, Universitas Mataram, Mataram, Indonesia
}

\begin{abstract}
Kata Kunci:
logika,

pemrograman, komputer, scratch, drone, pembelajaran, sekolah dasar
\end{abstract}

\begin{abstract}
Abstrak: Usia dini sebelum menginjak dewasa biasanya anak-anak cenderung bermain ataupun melakukan kegiatan lainya. Pemrograman sangat identik dengan kegiatan yang cukup menguras konsentrasi dan pola pikir sebagai seorang programmer, namun bukan berarti kegiatan pemrograman selalu erat kaitanya dengan orang dewasa. Salah satu aplikasi pemrograman komputer yang didesain khusus untuk anak usia 8 sampai 16 tahun adalah Scratch. Scratch dirancang untuk bermain, pembelajaran sendiri dan animasi. Scratch menggunakan "grafik" untuk mengajarkan logika pemrograman kepada anak. Tujuan dari kegiatan pengabdian kepada masyarakat ini adalah untuk mengenalkan dan menjelaskan pembelajaran logika dan algoritma pada anak usia tingkat dasar berbantuan aplikasi block programming scratch. Kegiatan ini dilakukan di SD Negeri Model Mataram. Metode pembelajaran yang dilakukan pada kegiatan ini adalah dengan cara belajar sambil bermain, membentuk kelompok, dan langsung praktik menggunakan laptop agar anak lebih mudah memahami materi yang disampaikan. Program komputer yang telah dibuat oleh anak akan diimplementasikan dalam mengendalikan sebuah Drone. Sebelum pembelajaran, anak akan diberikan angket kuesioner (angket I) dengan cara pengisian yang menyenangkan yaitu dengan cara menempel gambar pada angket tersebut. Kemudian, setelah dilakukan pembelajaran, anak akan diminta lagi untuk mengisi angket kuesioner (angket II) dengan cara yang sama. Hasil dari kegiatan ini berupa analisis pemahaman anak sebelum dan sesudah pembelajaran. Berdasarkan hasil kuesioner angket I, sebanyak 94\% anak belum pernah belajar logika pemrograman dan 69\% anak belum memahami cara Drone bekerja. Setelah dilakukan pembelajaran, berdasarkan hasil kuesioner (angket II), sebanyak 85\% anak memahami materi yang disampaikan, 98\% senang belajar logika pemrograman, dan 98\% anak berkeinginan untuk belajar logika pemrograman kedepannya.
\end{abstract}

\section{Korspodensi email: andy@unram.ac.id}

\section{PENDAHULUAN}

Dunia IT saat ini sedang menjadi primadona. Bukan karena dipandang keren dan sedang trend saja, tetapi karena manfaatnya sudah dirasakan nyata oleh masyarakat. Sekarang dan di masa yang akan datang, hidup di dunia ini bakal tidak jauh-jauh dengan yang namanya teknologi. Salah satu aspek krusial berkaitan dengan teknologi saat ini adalah koding. Koding tidak lain adalah aktivitas pemrograman komputer lewat penyusunan instruksi memakai bahasa pemrograman. Bagi anak IT, istilah ini sudah tidak asing lagi. Namun, untuk dunia pendidikan pada umumnya, istilah koding belum banyak terdengar. Pembelajaran koding di sekolah -sekolah sebenarnya telah diwacanakan untuk diterapkan bahkan mulai tingkat Sekolah Dasar (SD), pada tahun 2015 yang lalu. Hanya saja, untuk saat ini masih diimplementasikan oleh beberapa SMK (Sekolah Menengah Kejuruan). Karena hal ini 
merupakan kebutuhan, pembelajaran koding sepertinya akan masuk dalam kurikulum pendidikan secara nasional.

Koding lebih identik dengan mahasiswa jurusan IT. Artinya ada mindset bahwa pemrograman komputer hanya bisa dipelajari oleh anak usia kuliah. Hasil riset yang dilakukan oleh Microsoft (perusahaan digital raksasa dunia), menyebutkan 91\% siswa Indonesia tertarik lebih tahu banyak tentang koding. Sebanyak $72 \%$ sudah menginginkan koding masuk dalam pelajaran sekolah mereka. Jika diajarkan di SD, pembelajaran koding bukan bertujuan mencetak programmer yang sudah bisa membuat aplikasi dan game baru, melainkan sebatas pengenalan dan menyalurkan bakat anak-anak yang punya minat tinggi terhadap program komputer, sehingga ke depan mereka serius untuk menjadi programmer. Beberapa anak usia dasar di negara lain sudah lebih dulu menikmati pembelajaran koding dalam kurikulum belajarnya. Terutama Amerika Serikat, Estonia, Inggris dan Finlandia. Finlandia yang terkenal sebagai negara dengan sistem pendidikan terbaik dunia telah melahirkan programmer -programmer handal.

Salah satu aplikasi pemrograman komputer yang didesain khusus untuk anak usia 8 sampai 16 tahun adalah Scratch. Scratch merupakan bahasa pemrograman yang memudahkan penggunanya untuk membuat cerita, animasi, games, musik, dan seni secara interaktif (Raditya, 2017).

Permasalahan yang terjadi saat ini adalah banyak anak-anak usia tingkat dasar menghabiskan waktunya dengan bermain game. Game online sangat berkembang pesat akhir - akhir ini, semakin lama, permainannya semakin menyenangkan. Mulai dari tampilan, gaya bermain, grafis permainan, resolusi gambar dan lain sebagainya. Tak kalah juga bervariasinya tipe permainan seperti permainan perang, petualangan, perkelahian dan game online jenis lainnya yang membuat menariknya permainan. Semakin menarik suatu permainan maka semakin banyak orang yang memainkan game online tersebut. Saat bermain game, anak-anak tersebut biasanya lupa waktu dan mengurangi waktu belajar di rumah.

Tujuan dari kegiatan pengabdian kepada masyarakat ini adalah untuk memperkenalkan dan menjelaskan materi logika dan algoritma berbantuan komputer, memperkenalkan, menjelaskan, dan mengoperasikan perangkat lunak scratch, serta mendorong anak untuk menerapkan logika dan algoritma pada aplikasi scratch sehingga anak - anak usia tingkat dasar mampu membuat aplikasi versi mereka sendiri (salah satu contohnya adalah Game), membuat anak menjadi lebih produktif, imajinasi anak meningkat dan memiliki mindset baru. Alasan tim pengabdian memilih perangkat lunak Scratch karena perangkat lunak tersebut dapat menampilkan kegiatan dan hasil pemrograman secara visual dan menarik.

Kegiatan pengabdian kepada masyarakat ini diharapkan mampu memberi solusi atas permasalahan yang telah disebutkan sebelumnya. Diharapkan, anak akan mampu membuat game atau aplikasi versi mereka sendiri melalui koding. Manfaat kepada anak pada saat mereka ngoding yaitu pertama, anak akan belajar bahasa pemrograman, seperti mengenal berbagai fungsi dan simbol matematika. Kedua, anak ngoding untuk belajar menalar, menuliskan perintah dengan runtut dan tepat agar komputer dapat menjalankan perintah tersebut. Singkatnya, anak belajar penyelesaian masalah atau problem solving, membuat desain, dan seperti menulis pada umumnya, menyampaikan idenya. 
Kegiatan ini melibatkan 6 mahasiswa dari laboratorium 2 bidang jaringan dan embedded system PSTI FT UNRAM sebagai pendamping siswa SD dalam proses pelatihan. Target mahasiswa yang terlibat untuk memenuhi rasio 1:3 bersama 5 orang dosen dengan jumlah peserta pelatihan yaitu 20 orang murid SD. Peranan mahasiswa sangat penting mengingat murid SD umumnya aktif dan banyak bertanya karena memiliki rasa ingin tahu yang tinggi.

\section{METODE KEGIATAN}

Gambar 1 merupakan diagram alir yang menggambarkan metode pelaksanaan kegiatan atau langkah-langkah yang akan dilakukan dalam kegiatan pengabdian kepada masyarakat ini.

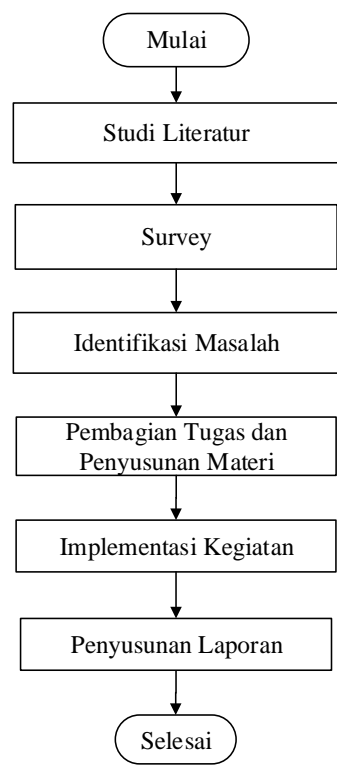

Gambar 1 Diagram alir pelaksanaan kegiatan

a. Studi Literatur

Pada tahap ini, dilakukan pengkajian terhadap berbagai sumber mengenai trend perkembangan teknologi terhadap anak dalam era globalisasi dan bagaimana pengaruhnya terhadap perkembangan anak. Sumber kajian diperoleh melalui berbagai sumber yang ada di internet.

b. Survey

Tim pengabdian melakukan survey ke Sekolah Dasar yang ada di Kota Mataram yang akan dijadikan lokasi pelaksanaan kegiatan pengabdian.

c. Identifikasi Masalah

Tim pengabdian melakukan observasi dan wawancara terhadap anak usia 10 sampai 13 tahun dalam menggunakan dan memanfaatkan teknologi yang ada pada saat ini.

d. Pembagian Tugas dan Penyusunan Materi 
Untuk dapat melaksanakan kegiatan ini, tim terlebih dahulu berkoordinasi untuk menentukan waktu pelaksanaan kegiatan, pembagian tugas dan peran masing-masing anggota serta penyusunan materi pengabdian. Tim menghubungi atau berkoordinasi dengan pihak Sekolah dalam hal ini diwakili oleh salah satu guru untuk mewakili sekolah untuk memberikan informasi kesediaan sebagai tempat kegiatan. Setelah mendapatkan ijin, tim menyiapkan surat dan bersurat kepada Kepala Sekolah untuk menentukan jadwal kegiatan pengabdian. Persiapan lainnya adalah diskusi dengan tim pengabdian untuk menyusun materi kegiatan.

\section{e. Implementasi Kegiatan}

Penyampaian materi dilakukan menggunakan slide power point dan hands-on langsung oleh para peserta kegiatan dalam hal ini siswa kelas 4 SD menggunakan beberapa laptop yang dimiliki oleh tim pengabdian. Laptop atau komputer yang digunakan telah terinstall program aplikasi Scratch. Tim Dosen dan beberapa mahasiswa yang terlibat akan mendampingi siswa dalam melakukan hands-on materi yang diberikan oleh tim pengabdian.

Pendekatan yang dilakukan oleh tim pengabdian yaitu dengan melakukan pendekatan eksplorasi, dengan harapan siswa dapat mencoba, memodifikasi dan selanjutnya dapat berkreasi menerbangkan drone dengan menggunakan perangkat lunak scratch. Siswa akan diperkenalkan logika dan algoritma berbantuan komputer, siswa diajarkan bagaimana mengoperasikan perangkat lunak scratch, mendorong siswa untuk menerapkan logika dan algoritma pada aplikasi scratch. Tahap-tahap pendekatan yang dilakukan yaitu siswa akan diajari dasar-dasar pemrograman, diawali dengan pengertian pemrograman, pembuatan program menggunakan flowchart, dan pengenalan perangkat lunak pemrograman scratch.

Rencana kegiatan yang akan dilakukan adalah sebagai berikut:

1. Menuliskan Flowchart untuk beberapa kasus

2. Pengenalan fungsi-fungsi dasar pada program Scratch

3. Praktik membuat program sederhana untuk menerbangkan drone menggunakan Scratch

4. Diskusi terkait pembuatan program menggunakan Scratch

\section{f. Penyusunan Laporan}

Pada tahap ini dilakukan penyusunan laporan akhir dari kegiatan pengabdian kepada masyarakat yang telah dilakukan.

\section{HASIL DAN PEMBAHASAN}

Tujuan dari kegiatan pengabdian kepada masyarakat ini adalah untuk mengenalkan dan menjelaskan pembelajaran logika dan algoritma pada anak usia tingkat dasar berbantuan aplikasi block programming scratch. Kegiatan ini dilakukan di SD Negeri Model Mataram dengan sasaran siswa kelas 4 SD.

Metode pembelajaran yang dilakukan pada kegiatan ini adalah dengan cara belajar sambil bermain, membentuk kelompok, dan langsung praktik menggunakan laptop agar anak lebih mudah memahami materi yang disampaikan. Program komputer yang telah dibuat oleh 
anak akan diimplementasikan dalam mengendalikan sebuah Drone. Sebelum pembelajaran, anak akan diberikan angket kuesioner (angket I) dengan cara pengisian yang menyenangkan yaitu dengan cara menempel gambar pada angket tersebut. Kemudian, setelah dilakukan pembelajaran, anak akan diminta lagi untuk mengisi angket kuesioner (angket II) dengan cara yang sama.

a. Membentuk Kelompok

Pada tahap ini dibentuk 6 kelompok dimana masing-masing kelompok terdiri dari 3 sampai 4 orang siswa. Tiap kelompok didampingi oleh 1 orang mahasiswa yang bertujuan untuk membimbing dan mengarahkan siswa. Meja dan kursi kelas diatur sedemikian rupa agar siswa duduk sesuai dengan kelompoknya dan memudahkan dalam kegiatan diskusi dan pembimbingan.
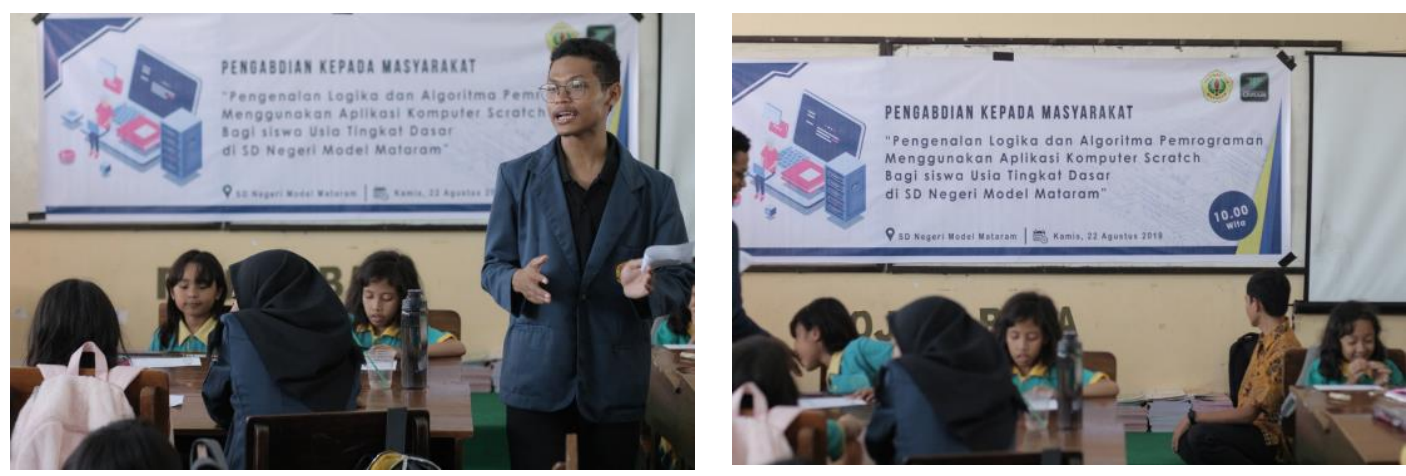

Gambar 2 Membentuk kelompok

\section{b. Pengisian Kuesioner (angket I)}

Pada tahap ini tim pengabdian ingin mengetahui terlebih dahulu pengetahuan anak tentang materi yang akan disampaikan dengan cara membagikan kuesioner kepada siswa. Pengisian kuesioner dilakukan dengan cara yang menyenangkan dan disesuaikan dengan usia siswa yaitu mengisi kuesioner sambil bermain, dimana siswa akan menempel gambar di angket tersebut.
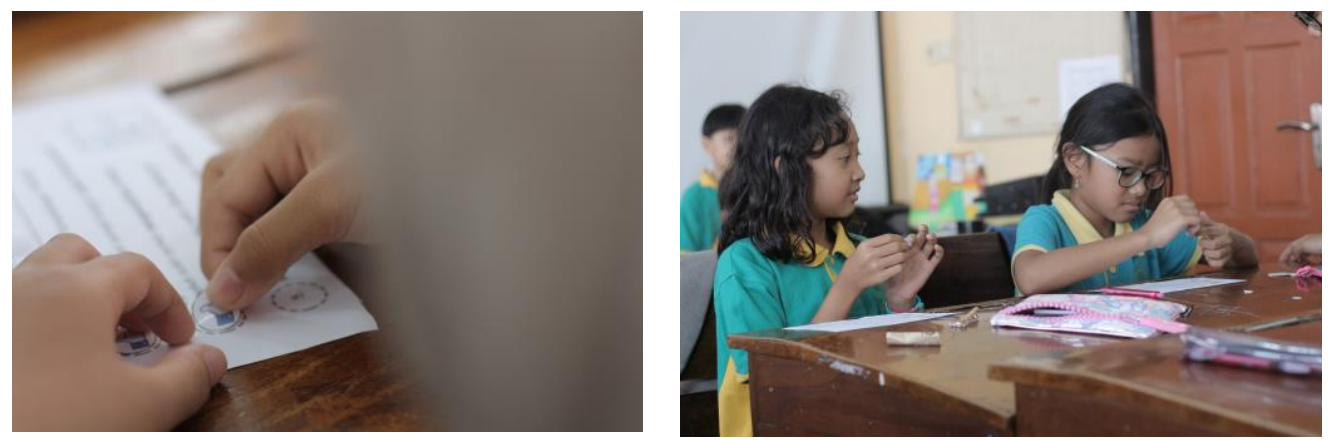

Gambar 3 Mengisi kuesioner I 
c. Praktik Membuat Blok Program Menggunakan Aplikasi Scratch

Setelah dilakukan pengisian kuesioner (angket I), siswa langsung melakukan praktik membuat program menggunakan aplikasi Scratch yang telah terinstall di laptop. Masingmasing kelompok dibimbing oleh satu orang mahasiswa. Siswa akan diperkenalkan terlebih dahulu jendela kerja aplikasi Scratch, fitur-fitur apa saja yang dimilikinya, dan diberikan pula satu contoh program sederhana. Setelah itu setiap siswa mencoba membuat program sendiri sesuai dengan kreatifitas mereka. Selama membuat program, siswa dibebaskan berdiskusi baik dengan temannya maupun dengan mahasiswa yang membimbing mereka.
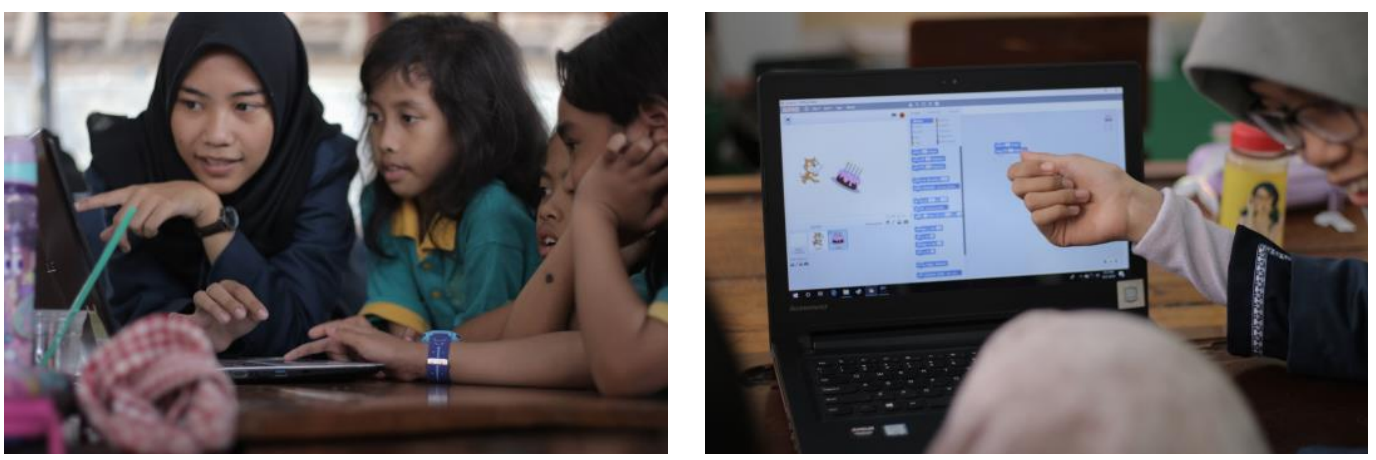

Gambar 4 Praktik membuat blok program

\section{d. Implementasi Program untuk Menerbangkan Drone}

Pada tahap ini dilakukan pengujian program yang telah dibangun oleh para siswa. Program akan diimplementasikan pada sebuah Drone. Drone akan terbang dan bergerak sesuai dengan perintah pada program yang telah dibangun oleh siswa. Dengan ujicoba menggunakan Drone ini, siswa merasa sangat senang dan antusias karena program yang mereka bangun berhasil diimplementasikan sesuai dengan materi yang disampaikan.
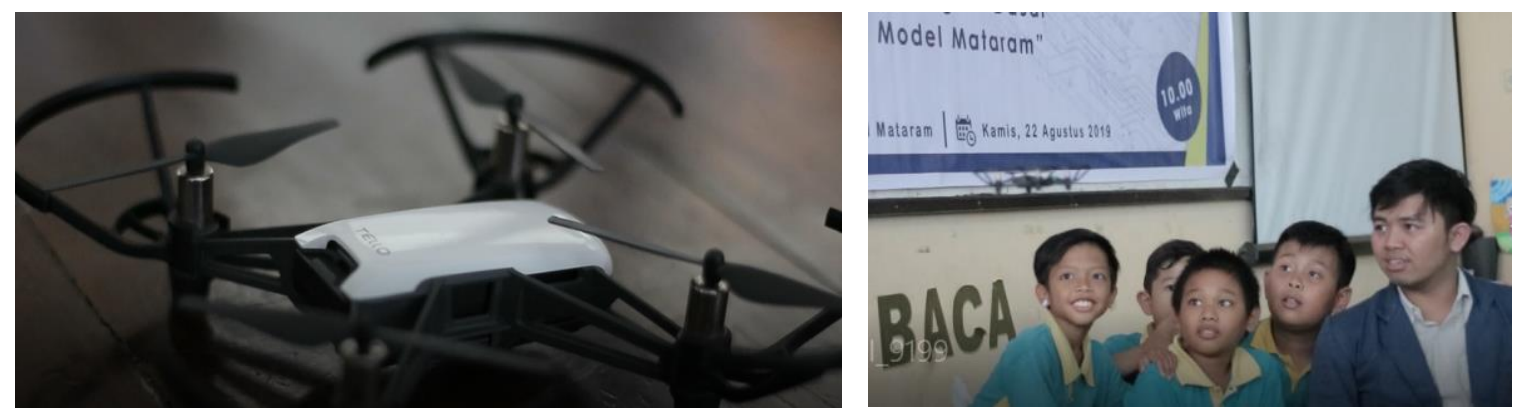

Gambar 5 Implementasi program menerbangkan Drone

\section{e. Pengisian Kuesioner (angket II)}

Setelah tahap ujicoba dan implementasi program selesai dilakukan, tahap berikutnya adalah pengisian kuesioner (angket II). Pengisian kuesioner ini dilakukan untuk mengetahui apakah siswa memahami materi yang disampaikan oleh tim pengabdian dan antusias untuk mempelajari lebih lanjut ke depannya. 

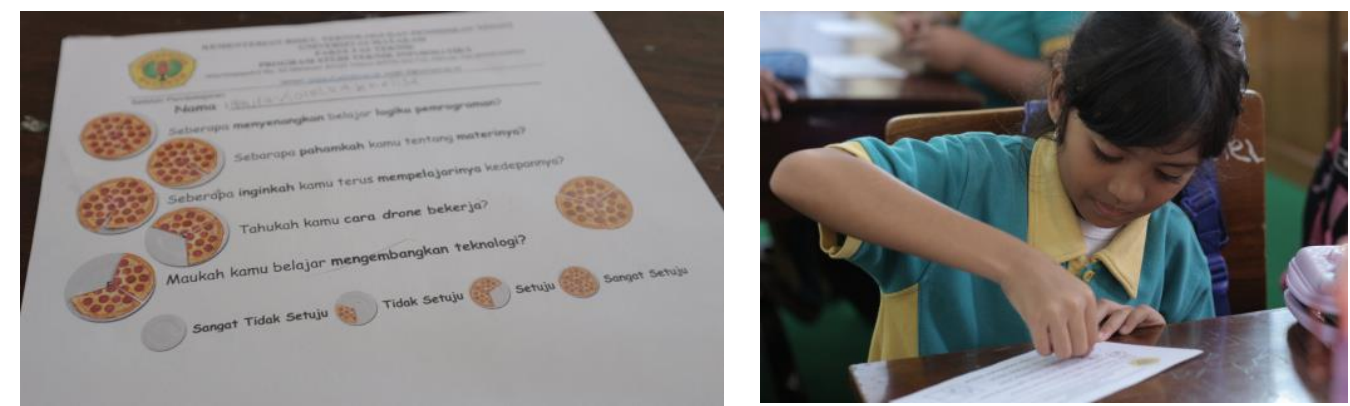

Gambar 6 Mengisi kuesioner II

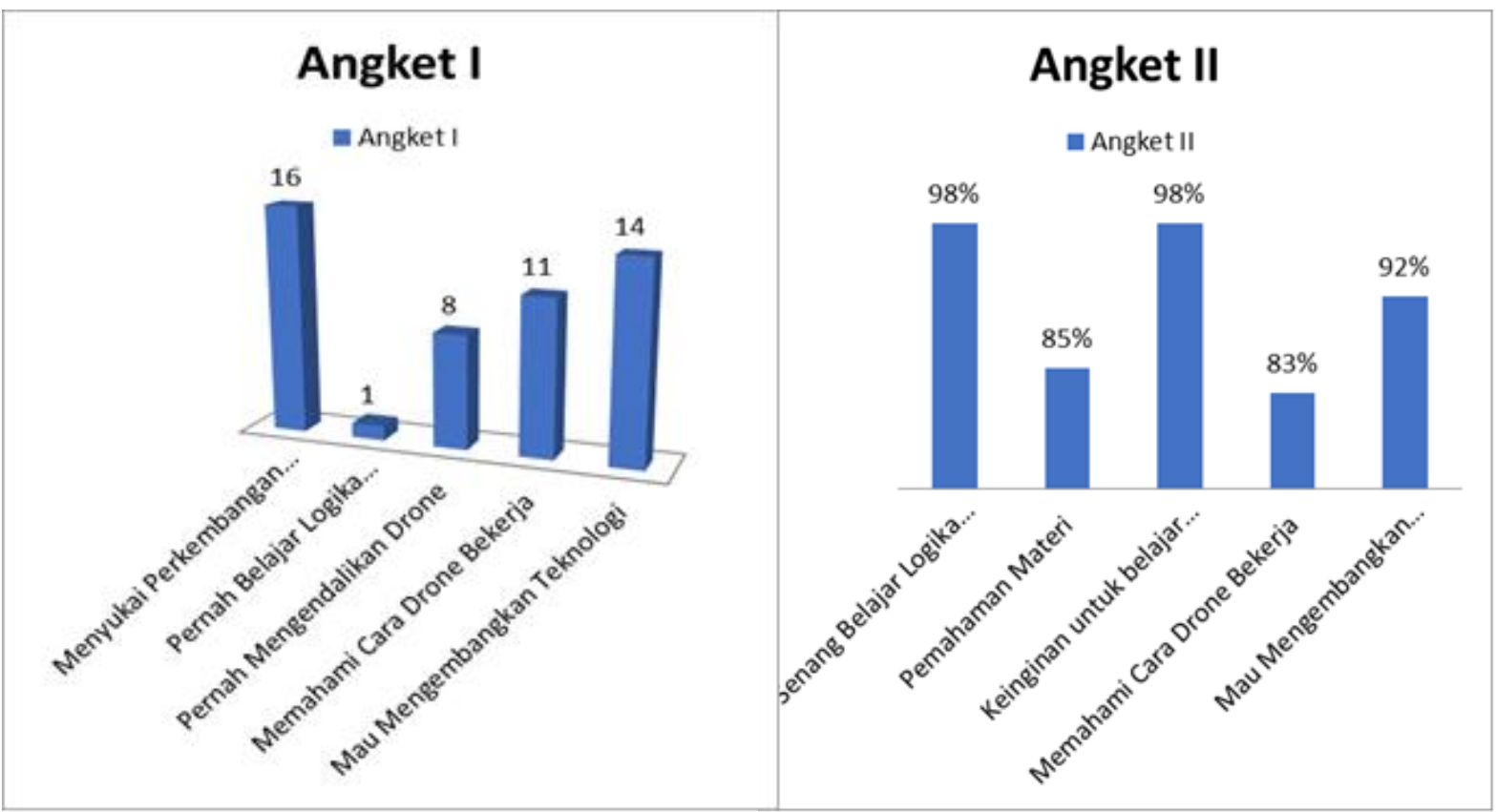

Gambar 7 Hasil pengisian kuesioner I

Gambar 8 Hasil pengisian kuesioner II

Gambar 7 merupakan hasil pengisian kuesioner sebelum pembelajaran dilakukan. Hal ini dilakukan untuk mengetahui pengetahuan anak tentang teknologi, logika, pemrograman, dan cara kerja Drone. Hasil kuesioner menunjukkan, 16 orang anak menyukai perkembangan teknologi, 1 orang anak pernah belajar logika pemrograman, 8 orang anak pernah mengendalikan Drone, 11 orang anak memahami cara Drone bekerja, dan 11 orang anak berkeinginan untuk mengembangkan teknologi.

Gambar 8 merupakan hasil pengisian kuesioner setelah pembelajaran dilakukan. Hal ini untuk memastikan apakah anak mampu menyerap materi dari metode pembelajaran dan pendekatan yang dilakukan tim pengabdian dalam hal penyampaian materi. Hasil kuesioner II menunjukkan $98 \%$ anak senang belajar logika pemrograman, $85 \%$ anak memahami materi yang disampaikan tim pengabdian, $98 \%$ anak berkeinginan untuk belajar logika pemrograman ke depannya, 83\% anak memahami cara Drone bekerja, dan $92 \%$ anak berkeinginan untuk mengembangkan teknologi. 


\section{KESIMPULAN DAN SARAN}

Berdasarkan hasil pengisian kuesioner I, proses pembelajaran dan penyampaian materi, serta pengisian kuesioner II dapat diambil kesimpulan dan saran sebagai berikut :

1. Berdasarkan hasil kuesioner angket I, sebanyak $94 \%$ anak belum pernah belajar logika pemrograman dan 69\% anak belum memahami cara Drone bekerja.

2. Setelah dilakukan pembelajaran, berdasarkan hasil kuesioner (angket II), sebanyak 85\% anak memahami materi yang disampaikan, $98 \%$ senang belajar logika pemrograman, dan $98 \%$ anak berkeinginan untuk belajar logika pemrograman kedepannya.

3. Untuk melakukan kegiatan yang serupa, disarankan untuk menambah jumlah Drone agar tiap kelompok memiliki Drone sendiri sehingga anak dapat lebih fokus dan leluasa dalam berkreatifitas.

4. Disarankan untuk menggunakan ruangan lebih besar agar tiap kelompok dapat menerbangkan Drone secara bersamaan.

5. Menerapkan metode pembelajaran lain yang lebih interaktif dan menyenangkan bagi anak usia tingkat dasar.

\section{DAFTAR PUSTAKA}

Ford, J. L. 2009. Scratch Programming for Teens. Boston: Course Technology.

Raditya, A., dan Baist, A. 2017. Pemrograman dengan Scratch. Modul Kuliah. Universitas Muhammadiyah Tangerang.

Sarah, R., Raditya, A. 2017. Pengembangan Bahan Ajar Project-Based Learning Berbantuan Scratch. Seminar Nasional Matematika dan Aplikasinya, Universitas Airlangga. 